\title{
Arms Control, Stability, and Causes of War
}

I

F THE MAIN OBJECTIVE OF ARMS CONTROL is to make war less likely, then any theory of arms control must rest on a theory of the causes of war. ${ }^{1}$ Most analysts start with the premise that the anarchical nature of the international system is crucial: armed conflicts occur because no higher authority can prevent them. ${ }^{2}$ This is consistent with the realist tradition, which has dominated American thinking since World War II and which informed the thinking of those who contributed to the Fall 1960 issue of Doedalus, even those who rejected much of this perspective. The central assumptions are that states are the main actors in international affairs, that the external environment is more important in determining states' behavior than their domestic characteristics, that this behavior was conditioned by the absence of an international sovereign, and that in this context states must be preoccupied with their own security.

Although this framework does not specify exactly when and where armed conflict will occur, it does give general directions to arms control. First, it tells us that we cannot eliminate the possibility of war without creating world government. Second, it points to states rather than individuals, economic classes, interest groups, bureaucracies, or transnational organizations as the sources of conflict and cooperation in international politics. Third, it could lead analysts to think about which kinds of systems are more war-prone than others. Indeed, there has been a great deal of research on whether bipolar or multipolar systems are more conducive to war. ${ }^{3}$ But because this factor cannot be altered, arms control analysts were drawn to the

Robert Jervis is Adlai E. Stevenson Professor of International Relations and member of the Institute of War and Peace Studies at Columbia University. 


\section{Robert Jervis}

ways in which states' security policies can produce wars that are inadvertent in the sense that they could have been avoided without sacrificing the states' core values.

It is now almost trivial to note that arms control is made possible by the fact that the superpowers have common as well as conflicting interests even -or especially - in the military arena and that cooperation and conflict are so closely linked that we can hardly analyze one without paying attention to the other. In the political and intellectual atmosphere of the late 1950s, however, this perspective did not come naturally. Memories of McCarthyism were still vivid; the claim that the United States had common interests with the Soviet Union could be seen as dangerously close to being "soft on Communism"; partly because the Soviet Union seemed to be gaining on the West in almost all respects, most members of the American elite were preoccupied with the task of competing with the Communist adversaries. Indeed, while liberals scorned the ideological rhetoric of the Eisenhower administration, they criticized it as much for its failure to develop a vigorous military posture as for its diplomatic clumsiness.

In this era, military policy and disarmament were considered quite separate, if not antithetical. Most of those who were concerned with disarmament believed either that such efforts could only follow a general reduction of conflict between the superpowers or, more frequently, that disarmament would produce such desired political changes. Thus, the linked arguments of the emerging arms control community that each superpower should be concerned about the other's military posture for reasons of mutual safety as well as for competitive advantage, and the view that disarmament and arms control were aspects of security policy, not alternatives to it, were major intellectual and political contributions.

\section{ARMS CONTROL POSTULATES}

Thomas Schelling emphasized "the possibility that one can simultaneously think seriously and sympathetically about our military posture and about collaborating with our enemies to improve it."4 $\mathrm{He}$ and Morton Halperin similarly introduced Strategy and Arms Control as follows: "The essential feature of arms control is the recognition of the common interest, of the possibility of reciprocation and cooperation even between potential enemies with respect to their 


\section{Arms Control, Stability, and Causes of War}

military establishments." 5 Note that the claim is not merely that the United States and the Soviet Union have some interests in common. Even the most hardened cold warriors were willing to see some areas where the superpowers could negotiate. But the stronger and less obvious argument is that it is in the area of military policy, where common sense and much previous discussion had located the highest degree of conflict, that the superpowers had major reasons to cooperate. In significant measure this argument rested on the broader development of deterrence theory and the claim that, in Brodie's familiar words: "Thus far the chief purpose of our military establishment has been to win wars. From now on its chief purpose must be to avert them. It can have almost no other useful purpose."6 A shift in the way war was viewed opened a space for arms control. Measures which were in both sides' military interests were precluded as long as people thought that wars were absolute struggles in which each side tried only to weaken, thwart, and harm the other and believed that the state could best prevent wars by being in the best position to defeat the other should war occur. As we will see later, many of the criticisms of arms control rest on this conception of deterrence.

By contrast, arms control rests on the theory that wars can occur because states have failed to realize the cooperation which their interests actually entail. For its centrality as well as its disagreement with previous views, the claim that hostile states almost always have important interests of military policy in common can be called the fundamental postulate of arms control. Although perhaps only one side can win a war, both could lose it in the sense of there having been at least one if not several outcomes that would have been mutually preferred to fighting. I use the word realize in two senses: to understand and to put into practice. Because the purpose of arms control research was not only academic, the two senses of realize were linked: it was hoped that as the intellectual explanation for the potential common interest gained plausibility, the superpowers would act on their improved understanding.

Closely related to this theme is the second postulate of arms control: arms control and security policy are not opposed to each other. "What we have tried to emphasize more than anything else," Schelling and Halperin noted in concluding Strategy and Arms Control, "is that arms control, if properly conceived, is not necessar- 
ily hostile to, or incompatible with, or an alternative to, a military policy properly conceived."7 "There is hardly an objective of arms control, that is not equally a continuing urgent objective of national military strategy —of our unilateral military plans and policies." 8 In the context of the 1950s, the idea of common interest between scholars concerned with avoiding war and the military was as surprising to some as the idea of common interest with the Soviet Union was to others. In fact, the two conceptions are linked. For if US-Soviet military relations were zero-sum, then it would have been difficult to find overlap between arms control and military policy. Again, what is central is the conception of war and how it might be prevented. To say that there is no conflict between intelligent arms control and intelligent unilateral military policy means that there must be significant common interest between the two sides, and that winning war in the sense of defeating the other's army can no longer be the dominant goal. Once one argues that conflict is inhibited because both sides realize that to engage in it is to leave them both worse off than if they had been more restrained, arms control is compatible with good military policy because our conception of what makes military policy good has changed. But-and these are troublesome points to which we will return-this claim was not made fully explicit, is subject to rebuttal on both theoretical and practical grounds, and has been the focus for later arguments, although not always couched in these terms.

\section{CRISIS STABILITY}

Although there are several ways in which arms control might help realize Soviet-American common interest and shape the conception of proper American military policy, the central contribution of the 1960 Dadalus writers was to emphasize the importance of crisis stability. Indeed, this has remained the focus of the theory and, to a lesser extent, the practice of arms control ever since. The basic idea is that even if both sides prefer peace to war, war could result through "the reciprocal fear of surprise attack" to use Schelling's well-known phrase.9 Thus Schelling and Halperin declare: "The most mischievous character of today's strategic weapons is that they may provide an enormous advantage, in the event that war occurs, to the side that starts it." 10 A first-strike advantage, coupled with the belief that war 
is very likely, if not inevitable, would make it rational for a state to attack even if it was peaceful because the alternative to attacking would be seen, not as peace, but as being attacked. Under these circumstances, the state's efforts to deter the adversary or protect itself in case of war would make war more likely. Observing the state's preparations, the adversary would see the danger of war increasing and would itself make ready to strike. While it was not much mentioned in the early literature, the obvious case which seemed to fit this model was the outbreak of World War I, although the relevant history is actually quite ambiguous and has been subject to fierce dispute. The crucial variables that the arms controllers focused on were the relative advantage of first as compared to a second strike (that is, the vulnerability of weapons systems and their associated apparatus) and the perceived likelihood of war. (We will return to a significant omission-the states' expectations about the value of a world that stays at peace.) Unlike some causes of war, these are manipulable by policy and so are particularly appropriate for a theory that can lead to actions.

\section{DOES THE STATE WANT THE ADVERSARY'S FORCES TO BE VULNERABLE?}

While it is clear then that the state should seek to keep the peace by decreasing the adversary's incentives to attack, should it decrease its own incentives to do so? That is, does it want the adversary's forces to be invulnerable and therefore its own population to be vulnerable? The first arms control postulate certainly implies that this could be the case: just because the adversary wants to reduce its vulnerability does not mean that this posture would be bad for the state. Indeed, the logic of crisis stability implies that the danger of war will be reduced if both sides are immune to surprise attack. But the early arms control literature rarely declared that the United States would be better off if the Soviet strategic forces were difficult to destroy.

There are three ways in which this argument might be joined that derive from different, but not conflicting, ways of analyzing the causes of wars. First, one can claim that crisis instability can cause wars without asserting that this is the only cause of war, or even the most important one. Schelling and Halperin imply pride of place to this danger when, in the sentence quoted above, they refer to first- 


\section{Robert Jervis}

strike advantage as "the most mischievous character of today's strategic weapons," 11 and the impression of importance is underlined by the lengthy discussion of the topic. But this position could only be justified by comparing this danger to others, which little arms control literature did. Furthermore, it is interesting that Schelling and Halperin do not say that the first-strike advantage poses the greatest danger of war, but rather that this is the most troublesome aspect "of today's strategic weapons." There then may be greater dangers arising from sources other than the weapons. The obvious questions are what these other dangers might be, whether concentrating on crisis stability distracts us from dealing with them and, indeed, whether increasing crisis stability, especially by decreasing the vulnerability of Soviet strategic forces, magnifies these other dangers.

These questions can be approached through a second avenue. The theory of war that focuses on crisis instability can be seen as a part of a more general theory that stresses the security dilemma and the spiral model of conflict. The security dilemma arises because many of the ways in which states try to increase their security have the unintended consequence of decreasing the security of others. The spiral model of conflict sees the resulting action-reaction dynamic as accelerated by each side's inability to understand the other or to see how the other is interpreting its own behavior. These processes generate and magnify conflict, leading to unnecessary wars. ${ }^{12}$ But wars can also start through the failure to deter the adversary: if threats led to insecurity and war in 1914, the British policy of conciliation and of taking full account of the supposed security needs of the other side produced war twenty-five years later. ${ }^{13}$ Deterrence theory, in brief, argues that wars are caused by states failing to develop the military strength and credible threats necessary to dissuade others from challenging the status quo. Furthermore, threats are most likely to be believed when the state can carry them out at reasonable cost, which in turn is more likely to be the case when the state can protect its own population (that is, if the adversary's strategic forces are vulnerable).

Deterrence theory and the spiral model then make very different arguments about the relationship between threats and vulnerability on the one hand and war on the other. Yet, the community of deterrence theorists overlaps very heavily with the community of arms controllers. And in some ways, deterrence and arms control are 
compatible, if not complementary. Both point to the importance of credibility and argue that threats and promises must be contingent; that is, the state must show the other that it can and will take actions the other does not want if and only if the other takes prohibited actions. But the two paths to war are quite different and in practice, although not in theory, the policy prescriptions often contradict each other. Arms control stresses the dangers that arise when reassurances and promises-especially the promise not to strike-are either not made or are not believed; deterrence stresses the dangers that arise when threats are absent or dismissed. Thus, when Schelling writes on arms control, he talks of the danger of inadvertent war and the necessity for reassurances that show the adversary that the state will refrain from attacking if the adversary will. When he writes on deterrence, he argues that war can occur if the state appears weak, and that it must show that it will not back down in the face of threats.

\section{NATURE AND INTENTIONS OF THE ADVERSARY}

To go further we need to turn to the third avenue and question of whether the state wants the other side's forces to be vulnerable. Classic arms control, like classic realism, sees the actors as essentially identical; discussions of crisis stability are couched in terms of two interchangeable actors. But other theories-those of Kant, Marx, and Wilson, for example-see the causes of war as lying within particular kinds of states. Far from ignoring domestic characteristics and treating all states as identical "billiard balls,"14 these theories assert that certain states cause wars by being aggressive. This is implicitly true for much deterrence theory. The language there often posits one side that is defending the status quo and another that is challenging it. The implication is that aggressive states cause wars and the problem is how to halt aggression rather than how to cope with offense-dominant technology and the security dilemma.

To see the prime cause of wars as stemming from the aggressive tendencies of some states is not automatically to dismiss the danger of crisis instability. Even if the adversary is highly aggressive, a mutually undesired war could come about through the reciprocal fear of surprise attack. To put the point more generally, even if the degree of conflict between the two sides is quite high, there is still room for some cooperation (that is, the first postulate of arms control can still 
hold). Indeed, even during World War II there were some restraints (on bombing cities at the start of the war and on not using poison gas throughout), although these may have been abetted by one side or the other miscalculating its own interests. Once nuclear weapons come on the scene, furthermore, the area of common interests expands because both sides need to avoid all-out war. Nevertheless, if one or both sides is highly aggressive, the range of applicability of the second postulate must be questioned. In many areas, good military policy will not be good arms control, and the attempt to render Soviet forces vulnerable might be an example.

The belief that the main cause of war is aggressive states is often linked to the claim that aggressiveness is correlated with, if not caused by, domestic repression. Although for years dismissed if not ridiculed by many arms controllers, this argument receives more than a little support from recent events. It is not likely to be an accident that unprecedented progress in arms control has occurred at the same time that the Soviet system has undergone unprecedented liberalization. Obstacles which were enormous when Brezhnev and his predecessors were in power have vanished with the Gorbachev revolution. This is not to say that all dangers have passed, or that nothing would have been possible without extensive changes within the Soviet Union, but it does appear that the success of arms control has been driven less by technological breakthroughs, intellectual ingenuity, and shifts in the balance of power than by internal changes which have affected the entire range of Soviet foreign policies.

\section{INTERESTS, DOCTRINES, AND STABILITY}

Those who argued that the United States should have extensive counterforce capability pointed out that not only can wars start through aggression, but also that although avoiding war is the central American interest, it is not the only American interest. The most obvious other American interest that could be threatened by invulnerable Soviet nuclear forces is Western Europe. The United States needs to deter against attacks on allies- "extended deterrence." The problem arises because of what Glenn Snyder has called the "stability-instability paradox." 15 If there is great stability at the strategic nuclear level, then there is little credibility in either side's threat to launch an all-out attack in response to anything other than an 
unlimited strike against it. ${ }^{16}$ The straightforward inference is that, in Colin Gray's words, "The United States cannot afford the crisis stability that precludes first use of strategic nuclear weapons." 17

It seems intuitively obvious that if there is crisis stability, neither side can credibly threaten to start an all-out war in response to a limited provocation. But this misstates the situation. It would be an accurate formulation if levels of violence were hermetically sealed off from each other, if undesired escalation were impossible. ${ }^{18}$ In fact, most statesmen realize that whenever violence is set in motion, no one can be sure where it will end up. Because events can readily escape control, limited responses carry with them some probability that the final, although unintended, result will be all-out war. A state that begins a confrontation or responds to one invokes what Schelling called "the threat that leaves something to chance." 19 What then brings pressure to bear on the adversary-and on the state as well-is less the immediate product of the action than the fear of where both states could end up.

The fact that the limited response would not automatically lead to all-out war means that the state can rationally carry it out under some circumstances, and that the threat to do so can be credible; the fact that the outcome could be mutual suicide means that the pressure generated is considerable. During the Cuban Missile Crisis, for example, both sides feared that the confrontation, although managed extremely carefully, could escalate to nuclear war. According to Arthur Schlesinger, Kennedy's sense of urgency toward the end of the crisis was "based on fear, not of Khrushchev's intention, but human error, of something going terribly wrong down the line." 20 Indeed, the incident that convinced the president that the situation was too dangerous to be permitted to continue was the shooting down of the U-2 over Cuba, which we now know actually represented an instance of these mechanisms because it was carried out by a local Soviet military officer against the wishes of Moscow. ${ }^{21}$

There are two implications for arms control. First, crisis stability need not leave allies dangerously exposed to threats. The fact that nuclear war could grow out of a conventional one means that even if the Soviets believed that they could win the latter, they could be deterred by the possibility of the former, whose occurrence would not depend on the vulnerability of their forces. Second, effective counterforce targeting is not necessary for deterrence. Arms controllers can 


\section{Robert Jervis}

argue for the virtues of mutual invulnerability without arguing against an effective military policy; the second arms control postulate is not invalidated by the state's need to protect its allies.

\section{IMPORTANCE OF DOCTRINE}

But if the need for extended deterrence need not disturb arms control, military doctrine can. The applicability of the fundamental arms control postulate is questionable if American leaders believe that in order to be secure, the United States must be able to insure that the Soviet Union-or any other adversary-could not gain a military lead over the United States in any kind of limited warfare. It can be argued that, even if unfortunate, deterrence indeed does impose such a requirement: if the United States were not able to match Soviet military power at all levels, the Soviet Union could be tempted to start a limited war. The stability-instability paradox would hold escalation in check; advantage at lower levels of violence could be turned into meaningful victory in war or coercion in peacetime. This view of military affairs is heavily zero-sum. Soviet and American security would be incompatible because only one side could have military superiority and only that side could be secure.

At the highest levels of violence, strong counterforce doctrines similarly conflict with the possibility, if not the desirability, of crisis stability. As long as both sides believe that all-out war would result in mutual devastation, first-strike incentives are negligible and crisis stability is relatively easy to attain. This is not true, however, if decision makers believe that there are real advantages to be gained by destroying more of the adversary's strategic forces than the state is losing. Because of multiple warheads, and, even more, because of the vulnerability of command and control facilities, a first strike will almost surely be advantageous in purely counterforce terms. A state that is preoccupied with counting surviving warheads, especially those with counterforce capability, will have significant incentives to strike first. While these incentives would not likely be high enough to be a menace in times of calm, they could be sufficient to create instability in periods of heightened tension and perceived likelihood of war. Theoretically, this need not be true, even if both sides adopted counterforce targeting. In principle, weapons and command systems could be so invulnerable that attacking would use up more warheads 
than it would destroy. But it appears that while the vulnerability of command and control systems can be reduced, it cannot be eliminated. In practice, then, it is probably true that the only thing worse than starting a counterforce war would be having to fight one after receiving the first blow.

To the extent that either or both sides believe that wars are only—or even are best—deterred by having a counterforce capability superior to that of the adversary, arms control is pointless or even dangerous. A status quo power with extensive commitments could seek crisis stability only if it had the ability to defend its allies on the nonnuclear level. But crisis stability itself would be hard to achieve because of the offensive advantage in a counterforce war. By contrast, if what deters is the risk of escalation and the threat that leaves something to chance, then both arms control postulates have a great deal of validity.

This perspective also reveals the limits of arms control. While both sides have an interest in eliminating extreme crisis instability, they need to see that there is some chance that events could get out of control once violence is employed because this is the main generator of caution and the primary means of exerting pressure on the other side. Given the complexity of large-scale military organizations and the unpredictability of human affairs, it is doubtful that arms control could succeed too well and produce arrangements that would drive the danger of undesired escalation close to zero. Furthermore, decision makers would probably ensure that this does not happen. That is, if crisis stability seemed to greatly reduce risks, it would permit, if not require, statesmen to take bolder actions during a crisis in order to produce the desired level of danger. ${ }^{22}$ Similarly, if decision makers believed confrontations were quite safe, they would feel freer to provoke them (that is, to challenge the adversary's important interests). If crisis management were seen as easy, there would be less pressure on statesmen to try to prevent crises from arising in the first place. (It is striking that we have gone more than a quarter of a century since the last major superpower crisis-this is longer than the main rivals stayed at peace in most of the prenuclear era.) If security is linked in part to the danger of inadvertent war, then too much stability could make the world safe for coercion and violence. Successful arms control is, then, at a certain distant point, selflimiting. 
Unless and until this point is reached, however, the fundamental and secondary arms control postulates are compatible with the role of force and threats with the nuclear age. But this does not mean that they meet the greatest dangers of war. The focus on vulnerability and first-strike incentives is excessively mechanistic. States start wars for political objectives, not because they see an opportunity or fear that the other side does. Indeed, it is hard to find even a single war that was inadvertent in the sense that, immediately after it started, both sides would have preferred to return to peace on the basis of the status quo ante. Of course the question is not one of either/or. Crisis instability can interact with political conflict, arms controllers never suggested that the former in the absence of the latter would yield war. They did not worry that British forces were vulnerable to an American, or even to a French, attack; but by concentrating on the dangers of offensive advantages and assuming rather than examining the political context, they may have both exaggerated the danger of crisis instability and generated excessive hope that technical arms control could bring peace, if not cooperation. There is much validity to the old Soviet criticism of American arms control as preoccupied with the military causes of war at the expense of considering the broader relations between the two countries. If relations remain extremely bad, war can occur even if strategic weapons are not vulnerable; if relations greatly improve, vulnerabilities will not be a major source of danger.

Wars are caused predominantly by conflicts of political interests. Clashing security requirements are not the only and, perhaps, not the most important sources of such conflicts. Incompatible desires for territory and dominance, hostile nationalisms and other ideologies, and assorted calculations that fighting can be of benefit are common causes of wars that lie beyond the ameliorative reach of arms control. As I noted earlier, crisis instability is an extreme and fast-acting example of the security dilemma. When the offense is dominant, states cannot make themselves secure without menacing-or even attacking - the adversary. But arms control theorists did not build on this insight and raise the question of whether American military and foreign policy was unnecessarily decreasing Soviet security and heightening Soviet-American conflict, probably because they shared the prevailing belief that the Soviet Union was driven more by the desire to expand than by the fear that the West would attack it. 
Concentrating on the danger of preemption and immediate desperation, arms control paid less attention to a preventive war which could be produced by the perception that the other side is steadily eroding the state's security.

The standard formula for crisis stability focuses on the size of the gap between the payoffs for striking first and for striking second. But this neglects the expected evaluation of a world in which war does not occur, which is irrelevant only when war is judged to be completely certain. As long as the state believes that there is a chance that war can be avoided, its decisions will be strongly influenced by how well it thinks it will do if peace is maintained. Thus, a state which is satisfied with the status quo and is optimistic about its future prospects will seek to preserve the peace and may refrain from striking even in the face of crisis instability. By contrast, a state which is highly dissatisfied and/or which believes that its position is likely to deteriorate badly if current trends continue can rationally strike even when the offense has only a slight advantage. ${ }^{23}$ Furthermore, one side's misguided military policy can contribute to the other's sense of threat and belief that its future fate is bleak unless it fights. While the fundamental and second arms control postulates still apply, the focus on military instability is too narrow, if not misleading.

When the costs of war are enormous, it is hard to see how one can start unless one or both sides believe that war is inevitable and that striking first is preferable to striking second. The theory that underlies most American arms control thinking then has a large measure of validity. But it excludes the broad political considerations which usually play such a large role in decisions to fight. Both the danger of aggression and the possibility of long-run spirals of hostility and fear have been more potent causes of war than has crisis instability.

\section{ACKNOWLEDGEMENTS}

I am grateful to Emanuel Adler, Barry Posen, and Steve Weber for comments.

\section{ENDNOTES}

${ }^{1}$ For good discussions of the causes of war, see Geoffrey Blainey, The Causes of War (New York: Free Press, 1973); and Jack Levy, "The Causes of War: A Review of 


\section{Robert Jervis}

the Theories and Evidence," in Philip Tetlock, et al., eds., Behavior, Society and Nuclear War, vol. 1 (New York: Oxford University Press, 1989), 209-333. Bernard Brodie argued that because the danger of Soviet-American war was so slight and because the destruction of such a war could not be limited, arms control should concentrate on its third objective of saving money: Bernard Brodie, "On the Objectives of Arms Control," International Security 1 (1) (Summer 1976): 17-36. There is quite a bit to be said for this view-and arms control may have contributed to the stability that Brodie noted.

2The classic statement is from Kenneth Waltz, Man, the State, and War (New York: Columbia University Press, 1954).

${ }^{3}$ Kenneth Waltz, Theory of International Politics (Reading, Mass.: Addison-Wesley, 1979).

4Thomas Schelling, "Reciprocal Measures for Arms Stabilization" Doedalus 89 (4) (Fall 1960): 892.

5Thomas Schelling and Morton Halperin, Strategy and Arms Control (New York: Twentieth Century Fund, 1961), 2.

6Bernard Brodie, The Absolute Weapon (New York: Harcourt Brace, 1946), 76.

7Schelling and Halperin, 141.

8Ibid., 4.

9Thomas Schelling, The Strategy of Conflict (Cambridge: Harvard University Press, 1960), chap. 9; Schelling, Arms and Influence (New Haven: Yale University Press, 1966), chap. 6.

10Robert Powell argues that under most plausible assumptions, the situation is not as dangerous as one might think: see "Crisis Stability in the Nuclear Age," American Political Science Review 83 (1) (March 1989): 61-76. I have argued that standard analysis neglects important psychological processes and dynamics: The Meaning of the Nuclear Revolution (Ithaca: Cornell University Press, 1989), chap. 5.

11Schelling and Halperin, 9.

12See John Herz, "Idealist Internationalism and the Security Dilemma," World Politics 2 (2) (January 1950): 157-80; Herbert Butterfield, History and Human Relations (London: Collins, 1951), 19-20; Arnold Wolfers, Discord and Collaboration (Baltimore: Johns Hopkins University Press, 1962), 83-86; Waltz, Man, the State and War, 198-223; and Robert Jervis, Perception and Misperception in International Politics (Princeton: Princeton University Press, 1976), 62-90.

13In fact, the history of neither case carefully matches the models that bear their names: see Robert Jervis, "War and Misperception," Journal of Interdisciplinary History 18 (4) (Spring 1988): 685-89.

${ }^{14}$ The billiard ball analogy comes from Wolfers, 4-19.

${ }^{15}$ Glenn Snyder, "The Balance of Terror and the Balance of Power" in Paul Seabury, ed., The Balance of Power (San Francisco: Chandler, 1964), 184-201. Similarly, Schelling and Halperin say: "If one of the things that prevents local wars is the fear of both sides that it will spiral to total war, then agreements which make it less likely that this will happen may end up making local war more likely. On the 


\section{Arms Control, Stability, and Causes of War}

other hand this could be a reasonable price for greater insurance that local war will not go to total war." Schelling and Halperin, 31; see also 62-3.

16In this discussion I will put the latter possibility aside, both because it is hard to imagine the circumstances which could lead to such a Soviet attack and because the problem is analytically parallel to that of extended deterrence. I will also assume that the conventional balance in Europe would permit the Soviets to conquer the continent if nuclear weapons were not used, and that both sides realize this is the case. In fact, this is hotly disputed.

17Colin Gray, "Strategic Stability Reconsidered," Daedalus 109 (4) (Fall 1980): 147.

${ }^{18}$ There is an important link between crisis instability and events getting out of control, although this connection was not explicitly drawn even by those who developed the concepts. When offensive advantage is slight (i.e., when even striking first will lead to disaster) it is hard to see how an all-out nuclear war could start. Thus, Herman Kahn argued that while crisis instability could be troublesome, "I have put this possibility low on the list of possible cause of war ... because of the belief that as long as decision makers are consciously in control of events, they are very much more likely to draw back from pressing buttons and accept any resulting risks, than to do something which would make war inevitable-particularly, if this war were to occur at a time and under circumstances not of their choosing." But as Kahn recognizes, a great deal rides on the proviso that "decision makers are consciously in control of events." Herman Kahn, "The Arms Race and Some of Its Hazards," Deedalus 89 (4) (Fall 1960): 760.

${ }^{19}$ Schelling, Strategy of Conflict, 187-203.

${ }^{20}$ Arthur Schlesinger, Jr., Robert F. Kennedy and His Times (Boston: Houghton Mifflin, 1978), 529. For more extended discussion of these fears and why they were well grounded, see Jervis, Implications of the Nuclear Revolution, 82-95.

${ }^{21}$ Richard Bernstein, "Meeting Sheds New Light on Cuban Missile Crisis," New York Times, 14 October 1987.

22For further discussion, see Jervis, The Meaning of the Nuclear Revolution, 96; and Barry Nalebuff, "Brinkmanship and Deterrence: The Neutrality of Escalation," Conflict Management and Peace Science 9 (2) (Spring 1986): 19-30.

${ }^{23}$ Under these circumstances, statesmen may also exaggerate the chances that war will bring victory. See Richard Ned Lebow, Between Peace and War (Baltimore: Johns Hopkins University Press, 1981). 